\title{
Narratives of progress: Zimbabwean historiography and the end of history \\ Ian Phimister*
}

\author{
Department of History, University of Sheffield, UK and University of Pretoria, South Africa \\ *Email: i.phimister@sheffield.ac.uk
}

The tradition of all dead generations weighs like a nightmare on the brains of the living (Karl Marx, Eighteenth Brumaire of Louis Bonaparte).

This brief commentary takes its inspiration from the opening address delivered by John Hoffman, and printed in these pages; that is, progress is usefully understood as a contradictory, contested and ambiguous process. But rather than attempt a comprehensive survey of the past 40 or so years of academic analyses of Zimbabwe's pasts, what follows has as its focus the emergence of 'patriotic history' and particularly its nationalist antecedents. These are critically examined. Although not concerned with the generality of recent studies that are neither nationalist nor materialist in orientation, this paper sketches in outline the rise, fall and rise of radical accounts. It ends by suggesting how such analyses might be taken forward.

Keywords: Zimbabwe; historiography; patriotic history; nationalism; political economy; Matabeleland

\section{Patriotic history}

According to Melber $(2011,89)$, the seizure of power by Southern Africa's national liberation movements 'signals in their understanding something similar to what Francis Fukuyama dubbed as the end of history'. From this perspective, national liberation is a just and historically necessary conclusion to the struggle between 'the' people and the forces of racism and colonialism. From this, two conclusions follow: the region's national liberation movements are progressive, and their coming to power marks the end of a process. For them to be overthrown would constitute a counter-revolutionary victory for reactionary forces. ${ }^{1}$ These are the assumptions underpinning 'patriotic history', even if the precise moment of its articulation has turned on the intensification of particular political struggles.

In the Zimbabwean case, this is an interpretation framed by many of Robert Mugabe's more recent speeches and pronouncements (Mugabe 2001). As understood by Sabelo Ndlovu-Gatsheni, the defining characteristics of 'patriotic history' are the central roles ascribed to land and race, circumscribed by loyalty to the liberation movement in the shape of ZANLA/ZANU. A further dimension has been the affirmation of Zimbabwe's sovereignty against external interference, especially where 
the latter has taken the form of selective Western support for human rights. ${ }^{2}$ For Blessing-Miles Tendi (2010a, 4), the essence of 'patriotic history' boils down to 'ZANU-PF as the alpha and omega of Zimbabwe's past, present and future'. To all intents and purposes, Zimbabwean history is reduced to a succession of chimurengas-never, it might be noted in passing, umvukelas-in which the present ruling dispensation is the only legitimate heir to the Nehanda and Kaguvi spirit mediums (Tendi 2010a, see also Tendi 2008, Tendi 2010b).

That this celebration of a violent past is narrowly self-serving has been easy enough to expose, and several important books and articles have done just that (Ndlovu-Gatsheni 2009, 234-98 and Tendi 2010b, see also Kriger 2006). But if indeed this particular political project by ZANU-PF does seek to mark the 'end of history', then the historiographical roots of the turn to 'patriotic history' merit closer scrutiny than they have so far received. Those who now piously enjoin us to distinguish between nationalist historians ('bad') and historians of nationalism ('good'), are themselves guilty of special pleading (Ranger 2004, 2005). They pass too lightly over political and intellectual sympathies manifest in the 1960s and 1970s and which endured until very recently. Although the behaviour of the child long since grown to adulthood is now an embarrassment to be shunned, the long-term responsibility of the parent should be acknowledged, particularly when parent and offspring have so much in common. These include the flattening of difference; the privileging of certain voices over others; and the identification of hegemonic nationalism as the bearer of improvement and progress.

\section{Nationalist history: from voices to silence}

Nowhere in Zimbabwean historiography is this tendency better exemplified than in the work of Terence Ranger. Some early studies aside (Ranger 1964, 1967a), his books and articles have exercised a generally pernicious nationalist influence for over a generation. From the fanciful extrapolations and factual misrepresentations in Revolt in Southern Rhodesia (Ranger 1967b); through the gloss applied in Peasant Consciousness and Guerrilla War (Ranger 1985), to the vicious excesses of the second chimurenga waged by ZANLA; by way of the tin ear first displayed in The African Voice (Ranger 1970) and again evidenced by Voices from the Rocks (Ranger 1999); to the celebration of the silence of the grave in 'Matabeleland Today' (Ranger 1989), ${ }^{3}$ these invariably provided usable pasts for an authoritarian nationalism under construction from the mid-1950s onwards. ${ }^{4}$ While each of these examples could be examined at length, constraints of time oblige this paper to look briefly at only two particular cases.

Ranger's Revolt in Southern Rhodesia (1967b) is the foundation on which much nationalist and 'patriotic' historiography rests. Yet for all that this book was much praised at the time, research conducted in the 1970s and early 1980s demonstrated beyond doubt that Revolt had got it spectacularly wrong in every important respect, even to the extent of misquoting crucial documents. Its crude nationalist underpinnings were first exposed by Julian Cobbing's scholarly account of the Ndebele Rising. The Ndebele umvukela, Cobbing concluded, did not witness 'the emergence of a leadership which was charismatic and revolutionary', as Ranger claimed. As the Ndebele had not been divorced from their 'traditional' leadership by the mid-1890s, the leading role ascribed by Ranger to religious leaders was quite simply wrong. They 
certainly did not co-ordinate a united Ndebele-Shona resistance against the whites. Nothing like the 'first act of "Zimbabwean" nationalism', the Ndebele Rising was rather 'the last act of the independent Ndebele state' (Cobbing 1977, 18 and Cobbing 1976).

If Cobbing's demolition of Ranger's explanation of the Ndebele Rising was not enough, it very soon became apparent that Revolt's chapters on the Shona rising were equally unreliable. In a series of closely argued articles and essay reviews, David Beach subjected Ranger's work to forensic scrutiny. The results demonstrated that Ranger's findings were unedifying, to say the least. Acknowledging that no assessment of Revolt could be complete 'without some reference to the political context in which it was written', Beach explained to his readers that at a time when the settler counter-revolution of UDI appeared to be going from strength to strength in the face of African disunity, Ranger's interpretation of the Risings seemingly offered hope for the future. With past divisions overcome under their new religious leadership, in Ranger's version the Ndebele and the Shona 'achieved almost complete tactical surprise, with a preconcerted, coordinated, almost simultaneous rising in each zone in March and June 1896'. In short, wrote Beach, 'Revolt served as a "charter for Zimbabwe as a focus for present-day political action"”. But in serving the interests of 1960s nationalism, it certainly wasn't good history. For Beach, Ranger's book turned far too much on inference, analogy and assertion, and too little on what the documents actually said. Contrary evidence had sometimes been omitted. On Beach's meticulous reading of every available file, there was nothing about the Shona rising, or risings, as he preferred to see them, to support Ranger's usable past. In neither Mashonaland nor Matabeleland had events come anywhere near to approximating 'the Rangerian model of a tightly-knit Ndebele-Shona religious high command organizing a pre-planned, simultaneous rising' (Beach 1979, 20 and Beach 1980). ${ }^{5}$ But precisely because it purported to reveal a history of united struggle against settler colonialism, a past shorn of ambiguity and complexity, Revolt was perfectly attuned to the needs of the new Jacobins.

Given that this article was conceived for a conference in Bulawayo, it is fitting that the focus of the second case study should be Matabeleland. ${ }^{6}$ Published in 1989 , Ranger's article purported to describe the situation in the west of the country in the second half of the decade (Ranger 1989, 161-2 and 172). ${ }^{7}$ Without once mentioning the murderous activities of the Fifth Brigade, his egregious account of Matabeleland instead emphasised Mugabe's generosity and courage. Although the author professed to be 'in no doubt about the scale of... the brutalities of 1983 and 1985', he wrote as if the 'balance of terror' was weighted most heavily on the side of the dissidents. Underpinned by the belief that there was 'almost no suspicion of me as a historian sympathetic to ZANU/PF', and seemingly oblivious to the possibility that informants located with the help of 'a guide provided for me by the District Administrator' might not be entirely forthcoming about state-sponsored mass violence in the very recent past, Ranger's article noted that there had been 'too many collapses of discipline, too many rapes, too many killings', but only on the part of dissidents. Beneficiaries of Mugabe's offer of an amnesty, the people of Matabeleland South's Matobo district had apparently, of their own accord, reached a general opinion: 'a condemnation of dissident violence' (Beach 1979, 20, 1980, 1986, Ch 5; Tsomondo 1977). That this prudent expression of opinion might have been influenced by popular memory of Bhalagwe Camp, the huge detention centre in the south of the district where 
thousands of villagers were detained and tortured by the Fifth Brigade (The Catholic Commission for Justice and Peace in Zimbabwe 2007, 223-31), was nowhere considered in this myopic view of Matabeleland's recent past.

\section{Alternative histories: radical history}

For all that 'patriotic history' and its nationalist antecedents were so manifestly wanting, alternative accounts, some initial successes notwithstanding, ultimately found it difficult to establish themselves within and without Zimbabwe. To begin with, it is not as if radical scholars were particularly slow off the mark after 1980. Despite the widespread tendency at Independence and afterwards, noted by Hoffman in his opening conference address, to see ZANU-PF as the embodiment of progressive politics, a number of notably critical voices were raised early on. Both Saul (1980) and Astrow (1983), for example, anticipated ZANU-PF's 'betrayal' of the revolutionary possibilities of the overthrow of colonialism, as did David Moore's close inspection of liberation struggle ideologies $(1988,1991)$. Over the course of that first decade, others followed suit, particularly Lionel Cliffe and Colin Stoneman, and the various contributors to the two volumes edited by the latter (Stoneman 1981, 1988; Stoneman and Cliffe 1989). Notable contributions by Zimbabwean scholars in much the same period were brought together in Zimbabwe. The Political Economy of Transition, 1980-1986 (Mandaza 1986). Edited by Ibbo Mandaza, its examination of the pattern of events since Independence was framed by an opening chapter by Mandaza himself. As the Second Chimurenga never 'encompassed within it even the idea of a socialist revolution', the postcolonial state was 'an apparent mediator between capital and labour... inclined towards controlling... popular demands' (Mandaza 1986).

Where scepticism was voiced about the so-called 'national democratic stage' of the revolution during the $1980 \mathrm{~s}$, however, it tended to bemoan the entrenchment of capitalism rather than lament the absence of democracy. Criticism was doubtless also muted by a reluctance to attack Zimbabwe's new rulers in a period of intensifying anti-apartheid struggle, but more damaging to the hard won 1970s gains of political economy (Phimister 1979) were the conservative consequences of the emergence of postmodernism and postcolonial studies in the northern hemisphere. While these latter developments questioned all grand narratives, subsequent intellectual convulsions affected radical analyses more than most, at least for a time, especially in the immediate aftermath of the collapse of the Soviet Union and so-called 'actually existing socialism'.

But although more and more historiographical space was occupied by nationalism's praise singers, ${ }^{8}$ it was never uncontested. Norma Kriger (1992) and Steven Robins (1996) exposed the glaring weaknesses of what the latter termed nationalism's 'praise texts'. Inside the country itself, the Economic History Department of the University of Zimbabwe, and latterly the Institute of Development Studies of the same institution, as well as a handful of individuals in other Departments and independent organisations, found continuing inspiration from historical materialism broadly conceived. To take the most prominent example, one of the first studies to explore the contextual limitations of democracy as practised by the region's militarist liberation movements was another collection of essays edited by Mandaza, this time together with Lloyd Sachikonye (1991). 
Labour history remained a key bastion of radical analysis. Research in this field by Brian Raftopoulos in particular (Raftopoulos 1995b; Raftopoulos and Phimister 1997; Raftopoulos and Yoshikuni 1999; Raftopoulos and Phimister 2000; Raftopoulos and Sachikonye 2001), ${ }^{9}$ served as a springboard for what was to become over the course of the 1990s and beyond, a series of wide-ranging and thorough-going critiques of authoritarian nationalism (Raftopoulos 2003; Raftopoulos and Savage 2005). Infused with political and intellectual urgency, these interventions were themselves hotly debated as academics on the Left struggled to understand the dynamics driving the post-2000 crisis in terms of rights versus redistribution (Yeros 2002; Moore 2004; Raftopoulos 2006; Moyo and Yeros 2007), ${ }^{10}$ a dispute which lost momentum once they were acknowledged as not necessarily mutually exclusive. They were anyway revised and taken up by a younger generation of scholars guided by Raftopoulos and Alois Mlambo, and published in 2009 as Becoming Zimbabwe (Raftopoulos and Mlambo 2009).

\section{Conclusion: becoming history}

This tightly edited and well-received collection marked not only a significant resurgence of radical scholarship, but also nicely exemplifies Hoffman's insistence that notions of progress are most usefully understood as complex and contested processes. More than this, it may also be that such processes are best approached through the interplay of local, national, regional and international contexts. In this way, for example, what Raftopoulos has memorably termed the 'discourse and destructive party accumulation project of ZANU-PF' (Raftopoulos 2010) would resonate beyond the region if located within the wider regimes of accumulation by dispossession identified by David Harvey (2003) as cited in Callincos 2009, 14). It is a point that was developed with particular force by John Saul when commenting on Hoffman's paper. Notions of progress, insisted Saul, are essentially political, not philosophical questions. The best studies of Zimbabwe's pasts have always understood this, foregrounding relations of power and exploitation, even as they placed them in historical context. With fluffy social histories entirely devoid of any understanding of political economy continuing to appear (Ranger 2010), only a renewed emphasis on contradictions and classes is likely to produce accounts of the past free of the nightmares of the present.

\section{Acknowledgements}

I am most grateful to David Moore and to an anonymous reviewer for their comments and suggestions.

\section{Notes}

1. For further discussion, see variously, Good (2002), Melber (2003) and Southall (2003).

2. The outstanding study in this regard is S. Ndlovu-Gatsheni, Do 'Zimbabweans' Exist? Trajectories of Nationalism, National Identity Formation and Crisis in a Postcolonial State (Bern 2009).

3. For pointed criticisms of these books and articles, see amongst others, Beach (1979), Cobbing (1977), Cross (1972), Kriger (1992), Robins (1996) and Phimister (2003). 
4. See especially Raftopoulos (1995), and Scarnecchia (2008). For a notably prescient analysis, see Slater (1975).

5. Both criticisms are discussed further in chapter five of Beach (1986). See also Tsomondo $(1977,13)$.

6. What follows is taken in part from Phimister (2008).

7. See also Ranger (2006), where it is claimed that 'human rights organisations did not publically condemn Zimbabwe in the 1980s'. This is contradicted by Lindgren (2005).

8. Amongst others, see Martin and Johnson (1981), Frederickse (1983), Lan (1985), Maxwell (1999), Ranger (1995, 1999).

9. Important materialist analyses written in this period on non-labour topics include Bond (1998), Bond and Manyanya (2002) and Mlambo (1997).

10. See also Moyo and Yeros (2005), Mamdani (2008), Chung (2006).

\section{Note on contributor}

Ian Phimister is currently Professor of International History at the University of Sheffield. He has held positions at the Universities of Zambia, Cape Town and Oxford. His research and publications cover Central and Southern Africa, as well as patterns of overseas investment associated with the City of London.

\section{References}

Astrow, A. 1983. Zimbabwe: A revolution that lost its way?. London: Zed Press.

Beach, D. 1979. Chimurenga: The Shona rising of 1896-7. Journal of African History 20: 395420.

Beach, D. 1980. Essay review. International Journal of African Historical Studies 13, no. 1: 103-108.

Beach, D. 1986. War and politics in Zimbabwe 1840-1900. Gweru: Mambo.

Bond, P. 1998. Uneven Zimbabwe. A study of finance, development, and underdevelopment. Trenton: Africa World Press Inc.

Bond, P., and M. Manyanya. 2002. Zimbabwe's plunge. Exhausted nationalism, neoliberalism and the search for social justice. Harare: Weaver Press.

Callincos, A. 2009. Imperialism and global political economy. Cambridge: Polity Press.

Chung, F. 2006. Re-living the second Chimurenga. Uppsala: Nordic Africa Institute and Harare: Weaver Press.

Cobbing, J. 1976. The Ndebele under the Khumalos, 1820 96. PhD thesis, University of Lancaster.

Cobbing, J. 1977. The absent priesthood: Another look at the Rhodesian risings of 1896-1897. Journal of African History 18.

Cross, S. 1972. Protest in Rhodesia. Transafrican Journal of History 5: 61-84.

Frederickse, J. 1983. None but ourselves. London: Penguin.

Good, K. 2002. The liberal model and Africa. Elites against democracy. Basingstoke: Palgrave.

Harvey, D. 2003. The new imperialism. Oxford: Oxford University Press.

Kriger, N. 1992. Zimbabwe's Guerrilla war. Cambridge: Cambridge University Press.

Kriger, N. 2006. From patriotic memories to patriotic history in Zimbabwe, 1990-2005. Third World Quarterly 27: 1151-69.

Lan, D. 1985. Guns and rain. Guerrillas and spirit mediums in Zimbabwe. London: James Currey.

Lindgren, B. 2005. Memories of violence: Recreation of ethnicity in post-colonial Zimbabwe. In No peace no war: An anthology of contemporary armed conflicts, ed. P. Richards, 158-64. Athens and Oxford: Ohio University Press and James Currey.

Mamdani, M. 2006. Lessons of Zimbabwe. London Review of Books 30: 17-21.

Mandaza, I., ed. 1986. Zimbabwe. The political economy of transition, 1980-1986. Dakar: CODESRIA.

Mandaza, I., and L. Sachikonye, ed. 1991. The one party state and democracy. The Zimbabwe debate. Harare: SAPES books. 
Martin, D., and P. Johnson. 1981. The struggle for Zimbabwe: The Chimurenga war. Harare: Zimbabwe Publishing House.

Maxwell, D. 1999. Christians and chiefs in Zimbabwe. A social history of the Hwesa People c. $1870 s-1990 s$. Edinburgh: Edinburgh University Press.

Melber, H. 2003. Limits to liberation in southern Africa. The unfinished business of democratic consolidation. Cape Town: HSRC Press.

Melber, H. 2011. Liberation movements as governments in Southern Africa-On the limits to emancipation. Strategic Review for Southern Africa 33: 78-102.

Mlambo, A. 1997. The economic structural adjustment programme: The case of Zimbabwe, 1990-1995. Harare: University of Zimbabwe Publications.

Moore, D. 1988. The Zimbabwean 'organic intellectuals' in transition. Journal of Southern African Studies 15: 96-105.

Moore, D. 1991. The Ideological Formation of the Zimbabwean Ruling Class, Journal of Southern African Studies 17: 472-95.

Moore, D. 2004. Marxism and Marxist intellectuals in schizophrenic Zimbabwe: How many rights for Zimbabwe's left? A comment. Historical Materialism 12: 405-25.

Moyo, S., and P. Yeros, ed. 2005. Land occupations and land reform in Zimbabwe: Towards the national democratic revolution. In Reclaiming the land: The resurgence of rural movements in Africa, Asia and Latin America, 165-209. London: Zed Books.

Moyo, S., and P. Yeros. 2007. Intervention: The Zimbabwe question and the two lefts, Historical Materialism 15: 171-204.

Mugabe, R. 2001. Inside the third Chimurenga. Harare: Government of Zimbabwe.

Ndlovu-Gatsheni, S. 2009. Do 'Zimbabweans' exist? trajectories of nationalism, national identity formation and crisis in a postcolonial state. Bern: Peter Lang.

Phimister, I. 1979. Zimbabwean economic and social historiography since 1970. African Affairs 78: 253-68.

Phimister, I. 2003. Doing violence to the past: Zimbabwe's new old history, Kronos. Journal of Cape History 29: 210-15.

Phimister, I. 2008. The making and meanings of the massacres in Matabeleland. Development Dialogue 50: 197-214.

Raftopoulos, B. 1995a. Gender, nationalist politics and the fight for the city: Harare 1940-1950s. Southern African Feminist Review 1: 30-45.

Raftopoulos, B. 1995b. Nationalism and labour in Salisbury 1953-1965, Journal of Southern African Studies 21: 79-95.

Raftopoulos, B. 2003. The state in crisis. Authoritarian nationalism, selective citizenship and distortions of democracy in Zimbabwe. In Zimbabwe's unfinished business: Rethinking land, state and nation in the context of crisis, ed. A. Hammar, B. Raftopoulos, and S. Jensen. Harare: Weaver Press.

Raftopoulos, B. 2006. The Zimbabwean crisis and the challenges for the left. Journal of Southern African Studies 32: 203-19.

Raftopoulos, B. 2010. The global political agreement as a "passive revolution": Notes on contemporary politics in Zimbabwe. The Round Table 99: 705-18.

Raftopoulos, B., and A. Mlambo, ed. 2009. Becoming Zimbabwe. Harare: Weaver Press.

Raftopoulos, B., and I. Phimister, ed. 1997. Keep on knocking: A history of the labour movement in Zimbabwe: 1900-97. Harare: Baobab Books.

Raftopoulos, B., and I. Phimister. 2000.Kana Sora ratswa ngaritswe": African nationalists and black workers - The 1948 general strike in colonial Zimbabwe. Journal of Historical Sociology 13: 289-323.

Raftopoulos, B., and L. Sachikonye, ed. 2001. Striking back: The labour movement and the post-colonial state in Zimbabwe 1980-2000. Harare: Weaver Press.

Raftopoulos, B., and T. Savage, ed. 2005. Zimbabwe: Injustice and political reconciliation. Cape Town: Institute for Justice and Reconciliation.

Raftopoulos, B., and T. Yoshikuni, ed. 1999. Sites of struggle: Essays in Zimbabwe's urban history. Harare: Weaver Press.

Ranger, T. 1964. The last word on Rhodes? Past and Present no. 28: 116-27.

Ranger, T. 1967a. The rewriting of African history during the scramble: The Matabele dominance in Mashonaland. African Social Research no. 4: 271-82. 
Ranger, T. 1967b. Revolt in Southern Rhodesia 1896-7. A study in African resistance. London: Heineman.

Ranger, T. 1970. The African voice in Southern Rhodesia 1898-1930. London: Northwestern University Press.

Ranger, T. 1985. Peasant consciousness and Guerrilla war. London: James Currey.

Ranger, T. 1989. Matabeleland since the Amnesty. African Affairs 88: 215-34.

Ranger, T. 1995. Are we also not men? The Samkange family and African politics in Zimbabwe 1920-64. London: James Currey.

Ranger, T. 1999. Voices from the rocks. Nature, culture and history in the Matopos Hills of Zimbabwe. Oxford: James Currey.

Ranger, T. 2004. Nationalist historiography, patriotic history and the history of the nation: The struggle over the past in Zimbabwe, Journal of Southern African Studies 30.

Ranger, T. 2005. Rule by historiography: The struggle over the past in contemporary Zimbabwe. In Versions of Zimbabwe: New approaches to literature and culture, ed. R. Muponde and R. Primorac. Harare: Weaver Press.

Ranger, T. 2006. Narrative and responses: The Zimbabwean case. Unpublished Paper, University of Connecticut.

Ranger, T. 2010. Bulawayo burning. The social history of a Southern African city 1893-1960. Woodbridge: Boydell and Brewer.

Robins, S. 1996. Heroes, heretics and historians of the Zimbabwe revolution. Zambezia 23: 7393.

Saul, J. 1980. Zimbabwe: The next round. Socialist Register 17: 170-202.

Scarnecchia, T. 2008. The urban roots of democracy and political violence in Zimbabwe: Harare and Highfield, 1940-1964. New York: University of Rochester Press.

Slater, H. 1975. The politics of frustration: The ZAPU-ZANU split in historical perspective. Kenya Historical Review 3: 261-86.

Southall, R. 2003. Democracy in Southern Africa: Moving beyond a difficult legacy, Review of African Political Economy 30: 255-72.

Stoneman, C., ed. 1981. Zimbabwe's inheritance. London: Macmillan.

Stoneman, C. 1988. Zimbabwe's prospects. Basingstoke: Macmillan.

Stoneman, C., and L. Cliffe. 1989. Zimbabwe: Politics, economics and society. London: Pinter.

Tendi, B-M. 2008. Patriotic history and public intellectuals critical of power. Journal of Southern African Studies 43: 379-96.

Tendi, B-M. 2010a. Making history in Mugabe's Zimbabwe. Politics, intellectuals and the media. Oxford: Peter Lang.

Tendi, B-M. 2010b. Zimbabwean history in context: A comparison of the history book with existent history curriculum and teaching. http://www.weaverpresszimbabwe.com/latestreviews/59-becoming-zimbabwe/317-review-of-becoming-zimbabwe-tendai-rtp.html

The Catholic Commission for Justice and Peace in Zimbabwe. 2007. Gukurahundi in Zimbabwe. A report on the disturbances in Matabeleland and the Midlands 1980-1988. New York: Columbia University Press.

Tsomondo, M. 1977. Shona reaction and resistance to the European colonisation of Zimbabwe, 1890-98. Journal of Southern African Affairs 2: 11-31.

Yeros, P. 2002. Zimbabwe and the dilemmas of the left. Historical Materialism 10: 3-15. 